\title{
Estimates of Genetic Variability for Seedling Traits in Fluted Pumpkin (Telfairia occidentalis Hook. F)
}

\author{
Lawrence Stephen Fayeun ${ }^{1 *}$, Lateef Akinkunle Hammed ${ }^{2}$, Olusegun Adebayo Oduwaye, \\ Jide Umar Madike ${ }^{3}$, Edith Uqueen Ushie ${ }^{3}$ \\ ${ }^{1}$ Department of Crop, Soil and Pest Management, The Federal University of Technology, Akure 704, Nigeria \\ ${ }^{2}$ Department of Horticulture, The Federal University of Agriculture, Abeokuta 2240, Nigeria \\ ${ }^{3}$ Department of Plant Breeding and Seed Technology, The Federal University of Agriculture, Abeokuta 2240, Nigeria
}

\begin{abstract}
An experiment was conducted to evaluate genetic variation among twenty-one fluted pumpkin genotypes for seedling traits. The seeds of the fluted pumpkin were germinated in nursery bags filled with saw dust at the Federal University of Agriculture, Abeokuta and the Federal University of Technology, Akure, Nigeria between July and August, 2013. The experiment was laid out in completely randomized design with three replications. Characters evaluated were emergence percentage (E\%), emergence index, emergence index rate, vine length $(\mathrm{cm})$, leaf area $\left(\mathrm{cm}^{2}\right)$, number of leaves, shoot dry weight $(\mathrm{g})$, and seedling vigour index $(\mathrm{SVI})$. Significant $(P \leq 0.05)$ differences were observed among the fluted pumpkin genotypes for the evaluated characters. High E\% was observed for genotypes Ftn45 (94.80\%), Ftn43 (93.30\%), Ftn57 (93.30\%), Fte41 (90.0\%), Ftn61 (86.70\%), and Ftm11 (83.30\%). Also, these genotypes had above average values for SVI. High phenotypic coefficients of variation and genotypic coefficients of variation were observed for leaf area $(75.44 \%)$ and dry shoot weight $(55.85 \%)$, respectively while heritability estimates above $50 \%$ was observed for leaf area $(82.0 \%)$, dry weight $(77.78 \%)$, E\% (70.84\%), and SVI (51.98\%). The genetic advance was high for E\% (38.37), SVI (38.09), and leaf area. SVI, E\%, vine length, and leaf area had significant positive correlation with most of the traits therefore, they can be used as selection criteria in fluted pumpkin. Therefore, genetic improvement of early seedling can be used for selection programme in fluted pumpkin.
\end{abstract}

Keywords Emergence, Genetic variability, Heritability, Correlation coefficient, Seedling vigour index

\section{INTRODUCTION}

Fluted pumpkin, Telfairia occidentalis (Hook F.) is one of the most important leaf and seed vegetables of West Africa. It is an indigenous crop of economic, nutritional and medicinal importance in the socio-cultural life of the people of southern Nigeria. Apart from consumption, the crop has significant use for sustainable land management and reclamation. Fluted pumpkin is a very fast growing crawler that branches profusely when the apical dominance is removed (Fayeun 2011) thereby encouraging good ground coverage which suppresses weeds and prevents direct impact of the sun on the soil. In addition, its root system ramifies in the top surface of the soil, thus preventing soil erosion. According to Asian Vegetable
Research Development Centre (1981), planting the crop in raised beds can reduce the effect of flooding during rainy seasons. Soyingbe et al. (2012), reported that its waste has potential for improving compost nutrient quality and thus useful as organic manure. Also, it has been reported that it can be used in bioremediation of heavy metal-polluted soil (Obute et al. 2001; Wegwu et al. 2002).

Despite the importance of this crop, its large scale production is limited by several factors including; inability to distinguish sex at early stage and the preponderance of males in natural populations (Ajayi et al. 2006), its recalcitrant nature (Akoroda 1990) and easy loss of viability due to its bulkiness and high moisture content which limit its long-term storage. These problems are compounded by the propensity of the seeds to germinate in

Received March 6, 2016; Revised April 17, 2016; Accepted April 18, 2016; Published May 31, 2016

*Corresponding author Lawrence Stephen Fayeun, lawrencefayeun@yahoo.com, Tel: +234-8030632197, Fax: +234-8099021294 
situ while in fruit. All these affect planting materials and seedling establishment. Limited research work has been directed at solving these identified problems. At present, seed is the only and reliable source of planting material used by farmers in this crop. Some proposed alternatives to seed might not be practicable and seem to be beyond the capability of small holder farmers. For instance, Esiaba (1982), Obiefuna (1995), and Sakpere et al. (2011) proposed the use of seed sections, rooted shoot tips, and rooting hormone (IBA) on vine cuttings, respectively.

Seedling parameters play important role in obtaining desirable crop stand (Malik et al. 2011). Good seedling vigour influences seed rate and gives crops competitive advantages over weeds and other environmental stresses which could consequently lead to reduced cost of production. Possibly, leaf and seed yield in fluted pumpkin can be predicted at the seedling stage which could help in predicting crop performance at maturity stage. Therefore, knowledge of genetic variability of seedling traits is needed for improvement of this crop. Information on the genetic components of variation, heritability and character association are needed for effective selection in plant breeding.
Reported research work on seedling traits of fluted pumpkin is rare. However, some works have been reported on fruit and seed traits. Odiaka et al. (2008) identified size of fruit, seed, leaf, and thickness of vine as trait indicators for quality seed for fluted pumpkin. Chukwudi and Agbo (2014) observed that large sized fruits gave higher seed sizes but medium sized fruits gave higher emergence rate. Attempts to improve the seedling traits of any crop can only be achieved if there is sufficient genetic variability in such traits. Crop improvement is dependent not only on the magnitude of phenotypic variability but also on the extent to which the desirable characters are heritable (Okelola et al. 2007). Therefore, it is important to partition phenotypic variation into heritable and non-heritable components and determine how heritable traits associate among themselves. Therefore, this study was carried out with the objective of determining the magnitude of genetic variation of seedling traits and character association in the twenty one fluted pumpkin genotypes across two locations.

Table 1. Places of collection and seed characteristics of the twenty one fluted pumpkin genotypes.

\begin{tabular}{llllccc}
\hline \multirow{2}{*}{ Genotype } & \multicolumn{2}{c}{ Places } & of collection & & Seed weight \\
& \cline { 2 - 4 } & Agro-ecology & State & Town & $\begin{array}{c}\text { Seed length } \\
(\mathrm{cm})\end{array}$ & $\begin{array}{c}\text { Seed width } \\
(\mathrm{cm})\end{array}$ \\
\hline Fts33 & Rainforest & Osun & Ikeji & 20.35 & 3.37 & 3.67 \\
Fty28 & Rainforest & Oyo & Ibadan & 22.45 & 4.50 & 4.67 \\
Ftn46 & Rainforest & Ondo & Igbara-Oke & 16.0 & 4.20 & 4.50 \\
Ftn45 & Rainforest & Ondo & Akure & 24.67 & 3.20 & 3.99 \\
Ftm11 & Rainforest & Imo & Orlu & 19.0 & 3.30 & 3.70 \\
Ftk16 & Rainforest & Ekiti & Emure & 8.0 & 3.0 & 2.90 \\
Fte42 & Derived savannah & Enugu & Enugu & 11.0 & 3.20 & 3.40 \\
Ftg22 & Derived savannah & Ogun & Abeokuta & 8.0 & 3.30 & 3.30 \\
Ftk21 & Rainforest & Ekiti & Emure & 13.20 & 4.0 & 3.80 \\
Fte41 & Derived savannah & Enugu & Enugu & 21.0 & 3.60 & 4.50 \\
Ftn44 & Rainforest & Ondo & Akure & 11.0 & 3.20 & 3.50 \\
Fty29 & Rainforest & Oyo & Ibadan & 17.60 & 4.0 & 4.80 \\
Ftn43 & Rainforest & Ondo & Igbara-Oke & 16.0 & 3.80 & 3.70 \\
Ftr15 & Rainforest & Anambra & Onitsha & 11.80 & 3.40 & 3.60 \\
Ftn57 & Rainforest & Ondo & Akure & 3.20 & 3.40 & 1.0 \\
Fte40 & Derived savannah & Enugu & Enugu & 11.0 & 3.20 & 3.50 \\
Ftn54 & Rainforest & Ondo & Akure & 11.90 & 30.73 & 3.14 \\
Ftn60 & Rainforest & Ondo & Igbara-Oke & 20.68 & 31.70 & 3.94 \\
Ftn62 & Rainforest & Ondo & Ondo & 15.40 & 3.10 & 3.80 \\
Fty31 & Rainforest & Oyo & Ibadan & 21.0 & 3.90 & 4.0 \\
Ftn61 & Rainforest & Ondo & Ogbese & 19.30 & 33.48 & 3.61 \\
\hline
\end{tabular}




\section{MATERIALS AND METHODS}

Twenty one genotypes of fluted pumpkin were collected from two agro-ecological zones (rainforest and derived savannah) in Nigeria. The genotypes used were freshly harvested fruits that were relatively of the same age. Their seeds were extracted on the same day and divided into two groups for use in the two experimental locations. The seeds characteristics of the 21 genotypes are presented in Table 1. The experiment was carried out between July and August, 2013 at the Teaching and Research Farm Directorate of the Federal University of Agriculture, Abeokuta, and Teaching and Research Farm of the Federal University of Technology, Akure. The two sites represent the main Agro-ecological zones of south western Nigeria. Abeokuta and Akure belong to the derived savannah and rainforest, respectively. The genotypes were grown in nursery bags $(12 \times 10 \mathrm{~cm})$ arranged in completely randomized design with three replications. The bags were separated from one another by $20 \mathrm{~cm}$ spacing, whereas the replications were separated by $50 \mathrm{~cm}$ spacing. A total of 105 bags were utilized at each location. The nursery bags were filled with white saw dust as suggested by Akoroda and Adejoro (1990) and watered. One seed was planted per bag under rain fed condition. However, supplementary watering was carried out as needed. Each plot contained five nursery bags and data were collected on four of them. Observations were made on eight different seedling traits. These are:

i. Emergence index (EI): Seedling emergence was recorded at $9,11,13,15,17$, and 19 days after planting (DAP) and used to compute EI according to modified formula of Fakorede and Ojo (1981).

$$
\mathrm{EI}=\sum \frac{\text { (Plants emerged in a day)(Day after planting) }}{\text { Plants emerged by } 19 \text { days after planting }}
$$

ii. Emergence percentage (E\%): This was calculated as the percentage of seedling emerged 21 DAP relative to the number of seeds sown per plot.

$$
\mathrm{E} \%=\frac{\text { Seeding emerged by } 21 \mathrm{DAP} \times 100}{\text { Number of seeds planted }}
$$

iii. Emergence rate index (ERI): This was computed by expressing $\mathrm{EI}$ as a proportion of $\mathrm{E} \%$ as follows:

$$
\mathrm{ERI}=\frac{E I}{E \%}
$$

iv. Seedling vigour index (SVI): This was computed according to the modified formula of Kharb et al. (1994).

$$
\mathrm{SVI}=\frac{(\text { Vine length }+ \text { root length }) \times \mathrm{E} \%}{100}
$$

v. Vine length: The length of the vine was measured in centimetre from the base of the plant to the tip with meter rule at 21 DAP.

vi. Number of leaves: The total number of leaves per plant was counted at 21 DAP.

vii. Leaf area: The leaf area was measured in square centimetre by scanning leaf samples with HP scanner and the area of scanned images were determined using a Leaf Area software (Bakr 2005) at 21 DAP.

viii. Shoot dry weight: Fresh shoot samples from each genotype were oven dried at $105^{\circ} \mathrm{C}$ for 24 hours and weight of the dry shoot samples were measured in gram with electronic balance.

The data obtained were subjected to analysis of variance (ANOVA) using PROC GLM of SAS ver. 9.1 (SAS Institute, Cary, NC, USA; Statistical Analysis System 2000). Mean effects that showed significant F-tests were separated with Duncan Multiple Range Test. Estimates of phenotypic and genotypic variances were calculated from the ANOVA. Broad sense heritability estimates $\left(\mathrm{H}_{\mathrm{B}}\right)$ was computed for each environment as the proportion of phenotypic variances that is due to genetic differences among genotypes; the broad sense heritability for the combined locations was estimated according to Tenkouano et al. (2002) as:

$$
H_{B}=\sigma^{2} g /\left(\sigma^{2} g+\sigma^{2} g e / l+\sigma^{2} e / r l\right)
$$

Where:

$\mathrm{H}_{\mathrm{B}}=$ the broad sense heritability,

$\sigma^{2} \mathrm{~g}=$ the genetic variance,

$\sigma^{2} \mathrm{gl}=$ the variance associated with genotype $\mathrm{x}$ location interaction,

$\sigma^{2} \mathrm{e}=$ the experimental error. 
The terms $\mathrm{g}, 1$ and $\mathrm{r}$ indicates the number of genotypes, location and replication.

Genetic advance (GA) was computed according to the formula given by Johnson et al. (1955) and as used by Fayeun et al. (2012).

$$
\mathrm{GA}=\frac{\sigma_{g}^{2}}{\sqrt{\sigma_{p}^{2}}} \mathrm{X} \mathrm{K}
$$

Where:

$\mathrm{K}=2.06$ (selection differential at 5\%)

Genotypic and phenotypic coefficients of variation were computed according to Singh and Chaudhury (1985) as follows.

Genotypic coefficients of variation $(\mathrm{GCV})=\frac{\sqrt{\sigma_{\mathrm{g}}^{2}}}{\bar{\chi}} \times 100$

Phenotypic coefficients of variation $(\mathrm{PCV})=\frac{\sqrt{\sigma_{\mathrm{p}}^{2}}}{\bar{\chi}} \times 100$

Where:

$\sigma_{\mathrm{g}}^{2}=$ Genotypic variation

$\sigma_{\mathrm{p}}^{2}=$ Phenotypic variation

$\bar{\chi}=$ Sample mean of the character

Analysis of covariance was carried out on pairs of variables and the resulting values were used to estimate the phenotypic correlation coefficients as suggested by Singh and Chaudhary (1985):

Phenotypic correlation coefficient $(\mathrm{r} p)=\frac{\operatorname{COV} p(X 1, X 1)}{\sqrt{\sigma_{\mathrm{p}(X 1)}^{2} \times \sigma_{\mathrm{p}(X 2)}^{2}}}$ Where:

$\operatorname{COV} p(X 1, X 1)=$ Phenotypic covariance among trait $\mathrm{X}_{1}$ and $\mathrm{X}_{2}$.
$\sigma_{\mathrm{p}(X 1)}^{2}$ and $\sigma_{\mathrm{p}(X 2)}^{2}=$ Phenotypic variance for traits $\mathrm{X}_{1}$ and $\mathrm{X}_{2}$, respectively.

Test of significance of correlation was done by comparing the computed values against table ' $r$ ' values given by Fisher and Yates (1963).

\section{RESULTS}

The analysis of variance indicated significant $(P \leq 0.01)$ differences among the 21 genotypes of fluted pumpkin for all the seedling characters evaluated in the study (Table 2). Significant location effect was observed for all the characters except for E\% and ERI. Also, significant genotype $\times$ location effect was observed for all the characters and this accounted for differential performance of the genotypes across the two locations. The mean value of the fluted pumpkin genotypes for the seedling characters evaluated across the two locations are presented in Table 3. High values of $\mathrm{E} \%$ and SVI was observed for genotypes Fte41 (90.0\% and 32.2, respectively), Ftn57 (93.3\% and 31.2, respectively), and Ftn45 (94.8\% and 31.98, respectively). Genotype Ftn 46 had the highest ERI of 29.8 but performed poorly in most of the other seedling traits. Genotype Ftm11 had the highest value for number of leaves (9.0) and shoot dry weight (1.3 g) and had above average values for all the seedling characters except ERI (15.4).

Estimates of genetic parameters of the eight seedling traits of 21 fluted pumpkin genotypes evaluated across two locations are presented in Table 4. Differences observed

Table 2. Mean squares for eight seedling traits evaluated in twenty one fluted pumpkin genotypes at two locations.

\begin{tabular}{|c|c|c|c|c|c|c|c|c|c|}
\hline $\begin{array}{l}\text { Source of } \\
\text { variation }\end{array}$ & $\mathrm{DF}^{\mathrm{z})}$ & $\begin{array}{c}\text { Emergence } \\
\text { percentage } \\
(\%)\end{array}$ & $\begin{array}{c}\text { Emergence } \\
\text { index }\end{array}$ & $\begin{array}{l}\text { Emergence } \\
\text { rate index }\end{array}$ & $\begin{array}{c}\text { Seedling } \\
\text { vigour index }\end{array}$ & $\begin{array}{l}\text { Vine length } \\
(\mathrm{cm})\end{array}$ & $\begin{array}{l}\text { Leaf area } \\
\qquad\left(\mathrm{cm}^{2}\right)\end{array}$ & $\begin{array}{l}\text { Number } \\
\text { of leaves }\end{array}$ & $\begin{array}{l}\text { Dry shoot } \\
\text { weight }(\mathrm{g})\end{array}$ \\
\hline Replicates & 2 & 248.40 & 11.00 & 8.75 & $6,351.41$ & 21.30 & 4.77 & 0.67 & 0.01 \\
\hline Genotypes (G) & 20 & $1,688.90 * *$ & $35.26 * *$ & $176.80 * *$ & $28,084.17 * *$ & $58.13 * *$ & $219.79 * *$ & $2.75 * *$ & $0.44 * *$ \\
\hline Locations (L) & 1 & $1,467.50$ & $10.77 * *$ & 77.22 & $42,936.24 * *$ & $1,560.11 * *$ & $869.81 * *$ & $5.37 * *$ & $1.07 * *$ \\
\hline $\mathrm{G} \times \mathrm{L}$ & 20 & $817.50 * *$ & $17.67 * *$ & $93.23 * *$ & $22,688.55^{* *}$ & $58.91 * *$ & $86.62 * *$ & $2.32 * *$ & $0.24 * *$ \\
\hline Error & 82 & 199.60 & 8.97 & 62.00 & $5,602.20$ & 17.68 & 15.01 & 0.74 & 0.04 \\
\hline CV (\%) & & 20.03 & 23.13 & 39.27 & 32.45 & 23.39 & 21.18 & 10.69 & 29.04 \\
\hline
\end{tabular}

**Significant at $\alpha=0.01$.

${ }^{z)} \mathrm{CV}$ : coefficient of variation; DF: degree of freedom. 
Table 3. Mean performance of 21 fluted pumpkin genotypes for seedling characters evaluated across two locations.

\begin{tabular}{|c|c|c|c|c|c|c|c|c|}
\hline Genotype & $\begin{array}{c}\text { Emergence } \\
(\%)\end{array}$ & $\begin{array}{c}\text { Emergence } \\
\text { index }\end{array}$ & $\begin{array}{l}\text { Emergence } \\
\text { rate index }\end{array}$ & $\begin{array}{c}\text { Seedling } \\
\text { vigour index }\end{array}$ & $\begin{array}{l}\text { Vine length } \\
(\mathrm{cm})\end{array}$ & $\begin{array}{l}\text { Leaf area } \\
\left(\mathrm{cm}^{2}\right)\end{array}$ & $\begin{array}{c}\text { Number of } \\
\text { leaves }\end{array}$ & $\begin{array}{l}\text { Dry shoot } \\
\text { weight }(\mathrm{g})\end{array}$ \\
\hline Fts33 & $76.70 \mathrm{a}-\mathrm{d}$ & $20.18 \mathrm{a}$ & $26.08 \mathrm{a}-\mathrm{d}$ & $23.70 \mathrm{a}-\mathrm{e}$ & $17.89 \mathrm{a}-\mathrm{e}$ & $23.37 \mathrm{a}-\mathrm{c}$ & $7.67 \mathrm{~b}-\mathrm{d}$ & $0.64 e-j$ \\
\hline Fty28 & $50.0 \mathrm{f}-\mathrm{h}$ & $11.71 \mathrm{~cd}$ & $27.82 \mathrm{ab}$ & $13.96 \mathrm{ef}$ & $16.69 \mathrm{~b}-\mathrm{f}$ & $19.33 b-e$ & $8.33 \mathrm{a}-\mathrm{d}$ & $0.55 \mathrm{j}-1$ \\
\hline Ftn46 & $65.0 \mathrm{c}-\mathrm{g}$ & $18.32 \mathrm{ab}$ & $29.84 a$ & $18.26 \mathrm{c}-\mathrm{f}$ & $15.94 b-f$ & $5.93 \mathrm{f}$ & $8.50 \mathrm{a}-\mathrm{c}$ & $0.46 \mathrm{~h}-\mathrm{m}$ \\
\hline Ftn45 & $94.80 \mathrm{a}$ & $15.15 b c$ & $15.81 \mathrm{c}-\mathrm{d}$ & $31.98 \mathrm{a}$ & $18.47 \mathrm{a}-\mathrm{d}$ & $16.35 \mathrm{e}$ & $8.88 \mathrm{ab}$ & $0.72 \mathrm{~d}-\mathrm{h}$ \\
\hline Ftm11 & 83.30a-c & $13.0 \mathrm{~cd}$ & $15.39 c-d$ & $29.42 \mathrm{ab}$ & $20.44 \mathrm{ab}$ & $23.84 \mathrm{ab}$ & $9.0 \mathrm{a}$ & $1.30 \mathrm{a}$ \\
\hline Ftk16 & $66.70 \mathrm{c}-\mathrm{f}$ & $11.22 \mathrm{~cd}$ & $18.35 \mathrm{~b}-\mathrm{e}$ & $16.47 \mathrm{~d}-\mathrm{f}$ & $11.60 \mathrm{f}$ & $9.86 f$ & $7.50 \mathrm{~cd}$ & $0.48 \mathrm{j}-\mathrm{m}$ \\
\hline Fte 42 & $40.0 \mathrm{~h}$ & $11.50 \mathrm{~cd}$ & $26.61 \mathrm{a}-\mathrm{c}$ & $17.15 \mathrm{c}-\mathrm{f}$ & $21.75 \mathrm{ab}$ & $21.07 \mathrm{a}-\mathrm{d}$ & $8.0 \mathrm{a}-\mathrm{d}$ & $0.61 \mathrm{f}-\mathrm{i}$ \\
\hline Ftg22 & $70.0 \mathrm{~b}-\mathrm{e}$ & $14.08 \mathrm{~cd}$ & $21.30 \mathrm{a}-\mathrm{e}$ & $25.74 \mathrm{a}-\mathrm{d}$ & 21.49ab & $23.07 \mathrm{a}-\mathrm{d}$ & 7.83a-d & $0.92 b-d$ \\
\hline Ftk21 & $46.70 \mathrm{~g}-\mathrm{h}$ & $12.39 \mathrm{~cd}$ & $27.03 \mathrm{ab}$ & $12.62 \mathrm{f}$ & $12.62 \mathrm{ef}$ & $6.70 \mathrm{f}$ & $6.0 \mathrm{~d}$ & $0.23 \mathrm{~m}$ \\
\hline Fte 41 & $90.0 \mathrm{a}$ & $12.56 \mathrm{~cd}$ & $12.67 \mathrm{e}$ & $32.15 \mathrm{a}$ & $20.76 \mathrm{ab}$ & $18.22 \mathrm{c}-\mathrm{e}$ & $7.83 \mathrm{a}-\mathrm{d}$ & $0.70 \mathrm{~d}-\mathrm{i}$ \\
\hline $\mathrm{Ftn} 44$ & $66.70 \mathrm{c}-\mathrm{f}$ & $11.82 \mathrm{~cd}$ & $19.44 a-e$ & $27.20 \mathrm{a}-\mathrm{c}$ & $19.92 \mathrm{a}-\mathrm{c}$ & $24.10 \mathrm{ab}$ & $8.67 \mathrm{a}-\mathrm{c}$ & $0.69 \mathrm{~d}-\mathrm{i}$ \\
\hline Fty29 & $46.70 \mathrm{gh}$ & $11.13 \mathrm{~cd}$ & $27.78 \mathrm{ab}$ & $13.31 \mathrm{f}$ & $17.65 \mathrm{a}-\mathrm{e}$ & $18.20 \mathrm{c}-\mathrm{e}$ & $8.0 \mathrm{a}-\mathrm{d}$ & $0.45 \mathrm{i}-\mathrm{m}$ \\
\hline $\mathrm{Ftn} 43$ & $93.30 \mathrm{a}$ & $13.36 \mathrm{~cd}$ & $14.02 \mathrm{e}$ & $28.94 \mathrm{ab}$ & $16.08 b-f$ & $15.38 \mathrm{e}$ & 7.83a-d & $0.43 \mathrm{j}-\mathrm{m}$ \\
\hline Ftr15 & 76.70a-d & $11.99 \mathrm{~cd}$ & $17.01 \mathrm{~b}-\mathrm{e}$ & $20.99 b-f$ & $16.98 \mathrm{a}-\mathrm{f}$ & $18.04 \mathrm{de}$ & $7.67 \mathrm{~b}-\mathrm{d}$ & $0.76 \mathrm{c}-\mathrm{g}$ \\
\hline Ftn57 & $93.30 \mathrm{a}$ & $11.52 \mathrm{~cd}$ & $12.17 \mathrm{e}$ & $31.21 \mathrm{a}$ & $20.81 \mathrm{ab}$ & $25.43 a$ & $8.33 a-d$ & $1.07 \mathrm{~b}$ \\
\hline Fte 40 & $83.30 \mathrm{a}-\mathrm{c}$ & $12.47 \mathrm{~cd}$ & $17.17 \mathrm{~b}-\mathrm{e}$ & $31.25 \mathrm{a}$ & $22.79 \mathrm{a}$ & $22.35 a-d$ & $8.67 \mathrm{a}-\mathrm{c}$ & $0.88 \mathrm{~b}-\mathrm{e}$ \\
\hline $\mathrm{Ftn} 54$ & $56.70 \mathrm{e}-\mathrm{h}$ & $11.93 \mathrm{~cd}$ & $21.25 \mathrm{a}-\mathrm{e}$ & $18.58 \mathrm{c}-\mathrm{f}$ & $17.75 \mathrm{a}-\mathrm{e}$ & $19.03 b-e$ & $7.17 \mathrm{~d}$ & $0.311 \mathrm{~m}$ \\
\hline Ftn60 & $56.70 \mathrm{e}-\mathrm{h}$ & $9.92 d$ & $17.81 \mathrm{~b}-\mathrm{e}$ & $20.07 b-f$ & $13.83 \mathrm{~d}-\mathrm{f}$ & $8.53 \mathrm{f}$ & $7.67 \mathrm{~b}-\mathrm{d}$ & $0.361 \mathrm{~m}$ \\
\hline Ftn62 & $76.70 \mathrm{a}-\mathrm{d}$ & $13.08 \mathrm{~cd}$ & $20.21 \mathrm{a}-\mathrm{e}$ & $23.48 \mathrm{a}-\mathrm{e}$ & $18.47 \mathrm{a}-\mathrm{d}$ & $25.69 a$ & $7.50 \mathrm{~cd}$ & $0.83 b-f$ \\
\hline Fty 31 & $63.30 \mathrm{e}-\mathrm{g}$ & $10.84 \mathrm{~d}$ & $17.01 \mathrm{c}-\mathrm{e}$ & $16.29 \mathrm{~d}-\mathrm{f}$ & $14.47 \mathrm{c}-\mathrm{f}$ & $19.23 b-e$ & $8.50 \mathrm{a}-\mathrm{c}$ & $0.56 \mathrm{~g}-\mathrm{i}$ \\
\hline Ftn61 & $86.70 \mathrm{ab}$ & $13.77 \mathrm{~cd}$ & $16.12 \mathrm{c}-\mathrm{d}$ & $31.91 \mathrm{a}$ & $20.88 \mathrm{ab}$ & $21.93 \mathrm{a}-\mathrm{d}$ & $8.50 \mathrm{a}-\mathrm{c}$ & $1.0 \mathrm{bc}$ \\
\hline Mean & 70.55 & 12.95 & 20.05 & 23.06 & 17.98 & 18.29 & 8.0 & 0.66 \\
\hline
\end{tabular}

Means in a column with the same letters are not significantly different by Duncan Multiple Range Test $(P \leq 0.05)$.

Table 4. Estimates of genetic parameters of 8 seedling traits of 21 fluted pumpkin genotypes evaluated across two locations.

\begin{tabular}{lcccc}
\hline \hline \multicolumn{1}{c}{ Characteristic } & $\begin{array}{c}\text { Phenotypic coefficient } \\
\text { of variability (\%) }\end{array}$ & $\begin{array}{c}\text { Genetic coefficient } \\
\text { of variability (\%) }\end{array}$ & $\begin{array}{c}\text { Broad sense } \\
\text { heritability (\%) }\end{array}$ & Genetic advance \\
\hline Emergence (\%) & 37.31 & 31.40 & 70.84 & 38.37 \\
Emergence index & 69.86 & 39.43 & 31.85 & 2.35 \\
Emergence rate index & 50.01 & 30.76 & 37.82 & 7.82 \\
Seedling vigour index & 49.41 & 35.62 & 51.98 & 38.09 \\
Vine length $(\mathrm{cm})$ & 31.65 & 20.74 & 42.94 & 5.01 \\
Leaf area $\left(\mathrm{cm}^{2}\right)$ & 75.44 & 24.57 & 82.0 & 15.42 \\
Number of leaves & 15.93 & 9.67 & 36.88 & 0.96 \\
Dry shoot weight $(\mathrm{g})$ & 63.32 & 55.85 & 77.78 & 0.68 \\
\hline
\end{tabular}

between PCV and GCV were higher for EI (30.4) and leaf area (50.9). Relatively high values $(>40 \%)$ of PCV were indicated for EI, leaf area, ERI, SVI and dry shoot weight while moderately high values ( $20 \%$ to $40 \%$ ) were observed for E\% and vine length. Dry shoot weight had high GCV value of $55.85 \%$ while had moderately high values except number of leaves. Heritability estimates (broad-sense) above $50 \%$ were observed for leaf area $(82.0 \%)$, dry shoot weight (77.8\%), E\% (70.8\%), and SVI (52.0\%). High heritability estimates were accompanied by high genetic advance for E\% (38.4\%), SVI (38.1\%), and leaf area $(15.4 \%)$ while other traits had relatively low genetic advance values.

The phenotypic correlation coefficients among the eight 
Table 5. Phenotypic correlation coefficients among the eight seedling traits in fluted pumpkin genotypes.

\begin{tabular}{|c|c|c|c|c|c|c|c|c|}
\hline Characteristic & Location & $\begin{array}{c}\text { Emergence } \\
\text { index }\end{array}$ & $\begin{array}{l}\text { Emergence } \\
\text { rate index }\end{array}$ & $\begin{array}{l}\text { Vine length } \\
\quad(\mathrm{cm})\end{array}$ & $\begin{array}{c}\text { Leaf area } \\
\left(\mathrm{cm}^{2}\right)\end{array}$ & $\begin{array}{l}\text { Dry shoot } \\
\text { weight }(\mathrm{g})\end{array}$ & $\begin{array}{l}\text { Number } \\
\text { of leaves }\end{array}$ & $\begin{array}{c}\text { Seedling } \\
\text { vigour } \\
\text { index }\end{array}$ \\
\hline \multirow[t]{2}{*}{ Emergence $(\%)$} & Abeokuta & $0.40^{* *}$ & $-0.88^{* *}$ & $0.94 * *$ & $0.34 *$ & 0.20 & $0.75^{* *}$ & $0.37^{*}$ \\
\hline & Akure & $0.30^{*}$ & $-0.67 * *$ & $0.43 * *$ & $0.37 * *$ & $0.44^{* *}$ & 0.23 & $0.89^{* *}$ \\
\hline \multirow[t]{2}{*}{ Emergence index } & Abeokuta & & -0.03 & $0.34 *$ & $0.30^{*}$ & $-0.39^{*}$ & 0.13 & 0.05 \\
\hline & Akure & & $0.44 * *$ & 0.18 & 0.22 & 0.16 & 0.11 & $0.27^{*}$ \\
\hline \multirow[t]{2}{*}{ Emergence rate index } & Abeokuta & & & $-0.83 * *$ & -0.17 & $-0.26^{*}$ & $-0.70^{* *}$ & $-0.33^{*}$ \\
\hline & Akure & & & $-0.26^{*}$ & -0.19 & $-0.25^{*}$ & -0.01 & $-0.61 * *$ \\
\hline \multirow{2}{*}{ Vine length $(\mathrm{cm})$} & Abeokuta & & & & $0.56^{* *}$ & 0.05 & $0.77 * *$ & $0.41 * *$ \\
\hline & Akure & & & & $0.88 * *$ & $0.83^{* *}$ & $0.38 *$ & $0.67 * *$ \\
\hline \multirow[t]{2}{*}{ Leaf area $\left(\mathrm{cm}^{2}\right)$} & Abeokuta & & & & & -0.07 & $0.60^{* *}$ & $0.47 * *$ \\
\hline & Akure & & & & & $0.70^{* *}$ & $0.27 *$ & $0.57 * *$ \\
\hline \multirow[t]{2}{*}{ Dry shoot weight (g) } & Abeokuta & & & & & & $0.50^{* *}$ & $0.28^{* *}$ \\
\hline & Akure & & & & & & $0.56^{* *}$ & $0.61 * *$ \\
\hline \multirow[t]{2}{*}{ Number of leaves } & Abeokuta & & & & & & & $0.60 * *$ \\
\hline & Akure & & & & & & & $0.29 *$ \\
\hline
\end{tabular}

*, $* *$ Statistically significant at 0.05 and 0.01 probability levels, respectively.

seedling traits of fluted pumpkin genotypes evaluated at two locations is presented in Table 5. At both locations SVI had positive and significant correlation with all the traits except ERI that had negative significant correlation with SVI. However, EI was not significant with SVI in Abeokuta. Generally, E\%, vine length, and leaf area had positive significant correlations with most of the traits across the two locations. Whereas, ERI had negative significant correlations with all the traits across the two locations except with EI in Akure. Locational differences were obtained in the values of correlation coefficients among some of the traits. For instance different results were obtained for EI and ERI in both locations.

\section{DISCUSSION}

Early seedling vigour is important to predict performance of individual plants in terms of survival, establishment, competition, and yield. Therefore, knowledge of genetic variability of seedling traits would aid in the choice of effective and efficient breeding method that will accelerate the pace of improvement in seedling traits. The genotypes used in this study were highly variable for the evaluated seedling traits. Hence, there is a potential for selection among the fluted pumpkin genotypes used in the study. Genetic variation in seedling traits among genotypes of crops like maize, cowpea, and rice have been reported by Fakorede and Ojo (1981), Ajala et al. (2003), and Okelola et al. (2007), respectively. Existence of large genetic variations have also been reported for some growth and yield traits in the crop (Aremu and Adewale 2012; Fayeun et al. 2012; Chukwudi and Agbo 2014; Fayeun and Odiyi 2015). It was observed that no single fluted pumpkin genotype had the highest value for all the seedling characters evaluated in the study. Therefore, this information on the variability of seedling characters among the genotypes will help guide hybridization in the breeding programme of fluted pumpkin. Accordingly, genotypes Ftn45, Ftn43, Ftn57, Fte41, Ftn61, and Ftm11 which had above average values for most of the seedling traits might be regarded as promising genotypes on which improvement can be based.

The relative values of PCV and GCV give an idea about the magnitude of variability present in a genetic population. The high values of PCV and GCV for the evaluated traits revealed that the genotypes used have broad base variation for these traits. Knowledge of heritability influences the choice of selection procedures used by the plant breeder to decide which selection methods would be most useful to 
improve the character, to predict gain from selection and to determine the relative importance of genetic effects (Waqar-Ul-Haq et al. 2008; Laghari et al. 2010). Therefore, the traits (leaf area, dry shoot weight, E\%, and SVI) with high heritability values have good selection potentials. The closer the heritability estimate of a character is to $100 \%$, the less the character is subjected to the environmental influence and the easier it is to make progress through selection (Ojo et al. 2006). Furthermore, the expression of these seedling traits (leaf area, dry shoot weight, E\%, and SVI) were under genetic factors, indicating low environmental influence. However, it has been emphasized that heritability alone has no practical importance without genetic advance (Najeeb et al. 2009). In this study, the high heritability estimates that accompanied high genetic advance for $\mathrm{E} \%$, SVI, and leaf area is an indication that these traits are governed by additive gene action and, therefore provides the most effective condition for selection (Tazeen et al. 2009). The moderate heritability estimates observed for EI and ERI might be due to the fact that they depend on other variables which are under environmental influence. According to Falconer (1980) more variable conditions reduce the heritability, whereas uniform conditions increase it.

Information on characters association in crop makes simultaneous selection of more than one character possible and the information is derived from correlation analysis. The fact that SVI E\%, vine length, and leaf area had positive and significant correlation with most of the traits might implies that, selection for any of these traits might lead to improvement of most other traits and they can be used as selection criteria in fluted pumpkin when breeding for improved seedling vigour and yield. Adeyemo and Fakorede (1995) have shown that seedling vigour can be used as a selection criterion when breeding for improved yield in maize. Also, Fayeun and Odiyi (2015) suggested that marketable leaf yield can be improved by selecting for vine length and leaf area in fluted pumpkin. The locational differences obtained in the values of correlation coefficients among some of the traits especially EI and ERI might due to significant location by genotype interaction observed in this study. Significant environment (location) by genotype interaction have been reported to complicate selection of superior genotypes (Magari and Kang 1993; Ebdon and Gauch 2002) and reduces correlation between phenotypic and genotypic values, thereby reducing selection progress (Fan et al. 2007). Therefore care must be taken when selecting for these type of traits (EI and ERI) because they appear to be highly influenced by the environment and would not be good selection criteria for the crop.

In conclusion, the study revealed wide genetic variability for E\%, EI, ERI, vine length, leaf area, SVI, and dry shoot weight. Genotypes Ftn45, Ftn43, Ftn57, Fte41, Ftn61, and Ftm11 which had above average values for most of the seedling traits evaluated in the study were the best genotypes. The estimates of heritability with genetic advance revealed that E\%, SVI, and leaf area had high selection values with less environmental influence. SVI, $\mathrm{E} \%$, vine length, and leaf area had significant association with most of the traits and they can be used as selection criteria in fluted pumpkin. Therefore, genetic improvement of early seedling vigour will be possible for the breeding programme in fluted pumpkin.

\section{REFERENCES}

Adeyemo MO, Fakorede MAB. 1995. Genetic variation for seedling vigour and its correlated response from selection for grain yield in tropical maize (Zea mays L.) population. Discov. Innov. 7: 111-119.

Ajala MO, Adebisi MA, Akingbogun OA. 2003. Variability for seedling vigour in tropical cowpea (Vigna unguiculata (L) Walp. Moor J. Agric. Res. 4: 54-59.

Ajayi SA, Berjak P, Kioko JI, Dulloo ME, Vodouhe RS. 2006. Responses of fluted pumpkin (Telfairia occidentalis Hook. F.; Cucurbitaceae) seeds to desiccation, chilling and hydrated storage. South Afr. J. Bot. 72: 544-550.

Akoroda MO. 1990. Ethnobotany of Telfairia occidentalis (cucurbitaceae) among Igbos of Nigeria. Econ Bot. 44: 29-39.

Akoroda MO, Adejoro MA. 1990. Pattern of vegetative and sexual development of Telfairia occidentalis Hook. F. Trop. Agric. 67: 243-247.

Aremu CO, Adewale DB. 2012. Origin and seed positional effect on sex ratio of Telfairia occidentalis Hook. F. 
grown in Savanna agro-ecology. Int. J. Plant Breed. Genet. 6: 32-39.

Asian Vegetable Research Development Centre (AVRDC). 1981. Annual report, p.88. AVRC-The World 381 Vegetable Centre, Shanhua, Taiwan.

Bakr EM. 2005. A new software for measuring leaf area, and area damaged by Tetranychus urticae Koch. J. Appl. Entomol. 129: 173-175.

Chukwudi UP, Agbo CU. 2014. Influence of fruit characteristics on seeds and seedling emergence of fluted pumpkin (Telfairia occidentalis Hook F.). J. Anim. Plant Sci. 24: 600-605.

Ebdon JS, Gauch Jr HG. 2002. Additive main effect and multiplicative interaction analysis of national turfgrass performance trials: I. Interpretation of genotype $\mathrm{X}$ environment interaction. Crop Sci. 42: 489-496.

Esiaba RO. 1982. Propagation of fluted pumpkin (Telfairia occidentalis) by seed sections. Proc. of the: 5th Conference of the Horticultural Society of Nigeria. Zaria, Nigeria.

Fakorede MAB, Ojo DK. 1981. Variability for seedling vigour in maize. Exp. Agric. 17: 195-201.

Falconer DS. 1981. Introduction to quantitative genetics. 2th ed. Longman, London, UK.

Fan X, Kang MS, Chen H, Zhang Y, Tan J, Xu C. 2007. Yield stability of maize hybrids evaluated in multi-environment trials in Yunnan, China. Agron. J. 99: 220-228.

Fayeun LS. 2011. Investigation into genetic diversity of the fluted pumpkin Telfairia occidentalis (Hook. F.) in Southern Nigeria [thesis]. Akure, Federal University of Technology.

Fayeun LS, Odiyi AC. 2015. Variation and heritability of marketable leaf yield components in fluted pumpkin. Sci. Agric. 11: 8-14.

Fayeun LS, Odiyi AC, Makinde SCO, Aiyelari OP. 2012. Genetic variability and correlation studies in the fluted pumpkin (Telfairia occidentalis Hook. F.). J. Plant Breed. Crop Sci. 4: 156-160.

Fisher G, Yates M. 1963. Statistical tables for biological, agricultural and medical Research. 6th ed. Hafner Pub. Co, New York, NY.

Johnson HE, Robinson HF, Comstock RE. 1955. Estimates of genetic and environmental variability in soybean. Agron. J. 47: 314-318.

Kharb RPS, Lather BPS, Deswal DP. 1994. Prediction of field emergence through heritability and genetic advance of vigour parameters. Seed Sci. Technol. 22: 461-466.

Laghari KA, Sial MA, Afzal Arain M, Mirbahar AA, Pirzada AJ, Dahot MU, et al. 2010. Heritability studies of yield and yield associated traits in bread wheat. Pak. J. Bot. 42: 111-115.

Magari R, Kang MS. 1993. Genotype selection via a new yield-stability statistics in maize yield trials. Euphytica. 70: $105-111$

Malik W, Iqbal MZ, Khan AA, Noor E, Qayyum A, Hanif M. 2011. Genetic basis of variation for seedling traits in Gossypium hirsutum L. Afr. J. Biotechnol. 10: 1099-1105.

Najeeb S, Rather AG, Parray GA, Sheikh FA, Razvi SM. 2009. Studies on genetic variability, genotypic correlation and path coefficient analysis in maize under high altitude temperate ecology of Kashmir. Maize Genet. Coop. Newsl. 83: 46.

Obiefuna JC. 1995. Improved technologies for sustainable production system of Telfairia occidentalis. Proc. of the: National Workshop on Foods and Vegetable. Ibadan, Nigeria.

Obute GC, Wegwu MO, Akaninwor JO. 2001. Determination of Lead accumulation and Toxicity in Telfairia occidentalis Hook F. (Cucurbitaceae) in the Niger Delta. J. Appl. Sci. Environ. Mgt. 5: 85-88.

Odiaka NI, Akoroda MO, Odiaka EC. 2008. Diversity and production methods of fluted pumpkin (Telfairia occidentalis Hook F.); Experience with vegetable farmers in Makurdi, Nigeria. Afr. J. Biotechnol. 7: 944-954.

Ojo DK, Omikunle OA, Oduwaye OA, Ajala MO, Ogunbayo SA. 2006. Heritability, character correlation and path coefficient analysis among six inbred-lines of maize (Zea mays L.). World J. Agric. Sci. 2: 352-358.

Okelola FS, Adebisi MA, Kehinde OB, Ajala MO. 2007. Genotypic and phenotypic variability for seed vigour traits and seed yield in West African Rice (Oryza sativa L.) genotypes. J. Am. Sci. 3: 34-41.

Sakpere AMA, Adelusi AA, Ajayi SA. 2011. Influence of indole-3-butyric acid on the vegetative propagation of fluted pumpkin (Telfairia occidentalis Hook. F.). Niger. J. Bot. 24: 289-301.

Singh RK, Chaudhary BD. 1985. Biometrical methods in quantitative analysis. Kaljuni Publishers, New Delhi.

Soyingbe AA, Hammed TB, Rosiji CO, Adeyemi JK. 2012. 
Evaluation of fluted pumpkin (Telfairia occidentalis, Hook F.) waste as nutrient amendment in compost for its effective management and crop production. IOSR J. Environ. Sci. Toxicol. Food Technol. 1: 32-38.

Statistical Analysis System (SAS). 2000. Online Doc. Version 9.0. Cary, NC, SAS Institute Inc.

Tazeen M, Nadia K, Farzana NN. 2009. Heritability, phenotypic correlation and path coefficient studies for some agronomic characters in synthetic elite lines of wheat. J. Food Agric. Environ. 7: 278-282.

Tenkouano A, Ortiz R, Baiyeri KP. 2002. Phenotypic and genetic correlations in Musa populations in Nigeria. Afr. Crop Sci. J. 10: 121-132.

Waqar-Ul-Haq, Malik MF, Rashid M, Munir M, Akram Z. 2008. Evaluation and estimation of heritability and genetic advancement for yield related attributes in wheat lines. Pak. J. Bot. 40: 1699-1702.

Wegwu MO, Obute GC, Osuji LC. 2002. Cadmium uptake by Telfairia occidentalis Hook. F. (Cucurbitaceae) grown in Cadmium-polluted soil. Glob. J. Pure Appl. Sci. 8: 497-500. 